San Jose State University

SJSU ScholarWorks

Faculty and Staff Publications

Library

January 2003

\title{
Economies of scale in the library world: the Dr Martin Luther King Jr Library in San Jose, California
}

Paul Kauppila

San Jose State University, paul.kauppila@sjsu.edu

Sharon Russell

San Jose Public Library

Follow this and additional works at: https://scholarworks.sjsu.edu/lib_pub

Part of the Library and Information Science Commons, and the Urban, Community and Regional Planning Commons

\section{Recommended Citation}

Paul Kauppila and Sharon Russell. "Economies of scale in the library world: the Dr Martin Luther King Jr Library in San Jose, California" New Library World (2003): 255-266.

This Article is brought to you for free and open access by the Library at SJSU ScholarWorks. It has been accepted for inclusion in Faculty and Staff Publications by an authorized administrator of SJSU ScholarWorks. For more information, please contact scholarworks@sjsu.edu. 


\title{
The authors:
}

Paul Kauppila is a Reference/Instruction Librarian at San Jose State University in San Jose, California. He may be contacted at: pkauppil@email.sjsu.edu.

Sharon Russell serves as the San Jose Public Library Program Manager for the new Dr. Martin Luther King, Jr. Library. She may be contacted at: sharon.russell@ci.sj.ca.us.

\author{
Keywords: \\ Joint library \\ Shared management \\ Operating agreement \\ Building design \\ Merged reference \\ Partnerships
}

\begin{abstract}
:
Describes the planning and construction of the new Dr. Martin Luther King, Jr. Library in San Jose, California, USA. This collaborative project between San Jose State University and the main branch of the San Jose Public Library utilizes a unique shared management system. The operating agreement defines the roles of each party within the co-managed facility. The overall philosophy of the building design and the building's interior floor plan are described. After a consultant's study of reference services was commissioned, it was decided that the new library would utilize a merged reference model. As library budgets continue to fall, joint library partnerships such as this one will become more common.
\end{abstract}

\section{Note:}

At the time of this writing, the proposed opening date for the Dr. Martin Luther King, Jr. Library is August 1, 2003, with a grand opening celebration scheduled for August 23, 2003. Please visit our website at: http://www.newkinglibrary.org/. 


\title{
Economies of Scale in the Library World: The Dr. Martin Luther King, Jr. Library in San Jose, California
}

\author{
by Paul Kauppila and Sharon Russell
}

The summer of 2003 will mark the opening of the largest co-managed joint-use library project ever - the Dr. Martin Luther King, Jr. Library in San Jose, California. The facility will house the collections of the San Jose Public Library's main branch and of San Jose State University's library system under one roof, with equal access for all users.

\section{The communities}

San Jose, California, the 11th largest city in the United States and the 3rd largest in California (approximate population 925,000), is located at the southernmost end of the San Francisco Bay, approximately 1 hour south of San Francisco. The current Dr. Martin Luther King, Jr. main public library is located in downtown San Jose, about 5 blocks from the San Jose State University campus. Although the public library system operates 18 separate libraries and a bookmobile, the main branch holds substantially more reference resources than any of the other branches. Consequently, the new Dr. Martin Luther King, Jr. library will serve the entire city and not just residents of the downtown area. The San Jose/Santa Clara County area is also one of the most ethnically diverse regions of the United States.

San Jose State University is a four-year state school and the oldest campus in the California State University system. Most degrees granted are bachelors and masters', although the Education department now offers a doctorate and it is likely that more $\mathrm{PhD}$ programs will be offered in the future. The main San Jose State University library building, Clark Library, was constructed in 1982. This building, which holds most materials published since 1980, also houses library administration, faculty, and staff offices, Academic Services, Technical Services, the Information Technology department, circulation functions, and student study spaces. Most older materials (up to 1980) are, at the time of this writing, housed in a facility known as Senter Storage, located on Senter Road, approximately two miles from campus. San Jose State's Special Collections can also be found in this building. The Cultural Heritage Center, located in a separate facility on campus, holds collections of African-American, Latin American, and Asian American materials. The new King library will consolidate these collections into one building, improving access for the university's core clientele of students, faculty, and staff.

\section{The beginning}

The project was conceived in 1996 through discussions between then-mayor Susan Hammer and San Jose State University president Robert Caret. The university desperately needed a new library building. The collection had outgrown Clark Library, and approximately fifty percent of the San Jose State University collection is currently housed in the offsite Senter Storage facility. Although these books can be retrieved by request, their off-campus location still presents access problems for students. The city had also outgrown its former main library building and had no more room to expand. 
In the California State University system, all 23 campuses compete for a limited pool of capital project funds. Campuses collaborating with other agencies for joint-use projects are more likely to receive CSU funding. Neither the city nor the university had the funding to construct separate new libraries to hold expanding collections, provide technology upgrades, and guarantee adequate seating for their growing communities. The mayor and president agreed that by pooling resources, they could build one new facility that would provide both city and university library users with access to more materials and services than either constituency would enjoy in separate locations.

Following a public announcement of their intent in 1997, the mayor and president directed a series of community forums to "test the waters" for this radical union of a major public and university library. People from the university and the community explored options about whether the project should be undertaken at all. Discussions covered where the library should be built, what architectural design was appropriate, and how it would be run. Opinions were heard ranging from "don't do this at all", to "maintain separate libraries within one building". However, the guiding principle thus far has been, "Merge everything that it makes sense to merge". Despite initial controversy, the final outcome was agreement on all sides to build.

\section{Site and size selection}

Both the city and the university had certain priorities regarding site selection and building design. These priorities were considered "deal-breakers", meaning that the project might not have gone forward had they not been addressed. As in many American cities, the downtown area of San Jose had fallen into blight and disrepair during the 1970s and 80s. In recent years, the city has made a strong effort to lure citizens and shoppers back to the city center. The City of San Jose's Capital Improvement Plan was designed to revitalize the downtown area and provide a civic focus attractive to both businesses and residents. The new King library is viewed by many local business and government leaders as an important part of that revitalization effort. In the city's case it was imperative that the chosen site "open" the campus to the city. Accordingly, the building will feature two main entrances - one public entrance opening onto Fourth and San Fernando streets, and one campus entrance opening to the university quad, symbolizing the union of the university with the larger community. This combined public/academic entrance design has been used by other joint library projects as well (Aird et al. 1998).

One of the university's highest priorities was to build a facility large enough to house the entire university library collection and to allow for 25 years of growth. With both sides in agreement about the location and size of the building, the southeast corner of San Fernando and Fourth Streets on the northwest corner of the campus was selected as the site of the new library. A groundbreaking celebration for the Dr. Martin Luther King, Jr. Library was held in October 2000. The new building will cover approximately 475,000 square feet, making it the largest American library west of the Mississippi River and the only co-managed facility of its size. 
The site itself has a long and interesting history - San Jose's first Carnegie Library opened at Fourth and San Fernando streets in 1903, followed by San Jose State's Wahlquist Library, which opened in 1942 on the same spot. Now, exactly 100 years later, the Dr. Martin Luther King, Jr. Library will open in the very same location. After a century of separation, this site, which seems destined to hold a library, will bring "town and gown" together.

In addition, the corner of Fourth and San Fernando is expected to become a keystone for the revitalization of the downtown core. One block to the north a new civic center and city hall will open in 2005 . The block to the west has new condominiums and apartment complexes at or near completion, all with retail at the ground floor level. A new city parking garage directly across the street will help accommodate the expected increase in visitors. Future plans also include a new performing arts complex north of the library. These projects will enhance the livability of the downtown area, which will draw future generations to the university and to Silicon Valley.

\section{The planning process}

The Operating Agreement was executed in December 1998. It defines the construction parameters, design and legal requirements, funding contributions, and roles of each partner during the development phase. Some of the issues addressed in the Operating Agreement are the mission of the new library, administrative responsibilities, organization of management, and avenues for conflict resolution between the two parties should serious disagreements arise. The university will retain ownership of the land, but the city holds a 50-year joint-tenancy agreement, with the option of 25-year renewals after that. The total project cost is estimated at $\$ 177.5$ million. The city's contribution is $\$ 70$ million, while the state is contributing \$86 million. San Jose State University will provide another $\$ 5$ million, and the remaining $\$ 16.5$ million is being raised from private sources.

San Jose Public Library and San Jose State University participants received training from outside consultants in team building, collaboration, and project management. The first consultant provided the tools for the teams to do their work, while the second provided an actual team structure. Results of these meetings determined the number and structure of the sub-teams charged with recommending policies and procedures. A Gantt chart was used to mark key dates in the timeline of the project. Members of the various sub-teams used Project Kick Start software to submit their work breakdown structure. Project managers then loaded this information into Microsoft Project software. After the subteams submitted their information to the Core Team and it was input into Microsoft Project, it was found that there were exactly three thousand two hundred and sixty-one tasks that needed to be performed! 


\section{Management structure}

The facility will be co-managed by the San Jose Public Library Director and the Dean of Libraries at San Jose State University. Merged units will be co-managed by department and division heads. Staff and collection development budgets, however, will remain separate.

The Senior Level Leadership Team includes San Jose's City Manager and Redevelopment Agency Executive Director and San Jose State's Vice President for Administration and Finance. The Core Team consists of the Dean and Associate Dean of the university library, the Director and Division Manager of the public library system, a program manager, and one project manager for each organization. The Core Team reports to the Senior Level Leadership team and provides leadership to the six major Strategic Operational Teams: User Services, Organizational Design and Development, Collections Management, Technology and Technical Services, Policies and Procedures, and Administrative Services. Each major team also oversees various subteams, such as the Reference Services Subteam, the Virtual Reference Subteam, the Government Documents subteam, etc. The Strategic Operational Teams make recommendations, but the Core Team is responsible for the final decisions.

\section{Building design, collections, and layout}

The executive architectural firm, Carrier Johnson of San Diego, California, and local architects Anderson-Brule all worked tirelessly to ensure a functional, attractive design. The design architect, Gunnar Birkerts, is well known for his use of natural light. The end result comprises eight floors above ground with a lower level and a mezzanine. The building rises 4 floors and then rotates 25 degrees on its own axis, symbolizing the unity of town and gown. The escalators will lead from the ground to the fourth floor, while the elevators will transport patrons between all floors. The building design provides quiet research and reflective space on the upper floors, while the more kinetic collections and activities are located on the first four floors and mezzanine.

The eight-story Dr. Martin Luther King Jr. Library will house about 1.4 million volumes with expansion capacity to 2 million volumes over a 25 -year period. Technical services, bound magazines and journals, government publications, and San José Public Library's Juvenile Resource Collections will be located on the lower level. The ground floor will showcase a browsing library of mostly popular fiction, a café, a library bookstore, a computer lab, the Center for Literacy, and the children's library. The mezzanine, overlooking the children's room, shares the K-12 educational resource collection with a separate children's exploration room for programmed activities. The non-circulating reference collection resides on the second floor, along with three computer labs, the adaptive technology center (featuring accommodations for individuals with special needs), the Technology Showcase, and lecture/meeting rooms. Much of the public library's circulating general collection (including materials in 58 different languages) will be located on the third floor. Other departments found on this floor include the public library's special collection of materials on the life of Dr. Martin Luther King, Jr., and the Teen Center. Current periodicals will be on the fourth floor, along with administrative, staff, and faculty offices. The fifth floor will showcase several special collections: the 
Martha Heasley Cox Center for Steinbeck Studies, the Ira F. Brilliant Center for Beethoven Studies, San Jose State University Special Collections, San Jose Public Library's California Room, and the San Jose State University Cultural Heritage Center: Africana, Asian-American, and Chicano. This floor is designed with a rooftop terrace available for special events and will also feature display cases and lighting designed to create a gallery-like atmosphere. Floors 6 through 8 will house the university's research collection. The eighth floor tops off the library with the Grand Reading Room, offering panoramic views of the city and the university. Hundreds of public computer terminals will be scattered throughout the building. Additionally, over 3000 network connection sites will be available so that patrons can use their own computers to access the Internet. Approximately 40 small group study rooms are distributed throughout the building.

\section{Reference services}

During the planning process, there was considerable disagreement about the design and delivery of reference services in the new library. One of the guiding principles of the project has been "seamless service" - that is, patrons should not be affected by the "joint" nature of the new library. Nevertheless, there were strong differences in opinion regarding reference. Some university librarians believed that two separate reference desks and collections were needed. Public librarians tended to disagree. To make matters worse, in December 1998 San Jose State University's Academic Senate passed a resolution stating that SJSU students would have their research and information needs met by San Jose State University librarians. How this would work in practice was not defined, but librarians from San Jose Public worried that their academic colleagues were undervaluing their professional skills.

The team responsible for the design and delivery of reference services decided to hire a consultant, Dr. Thomas Childers of the College of Information Science and Technology at Drexel University, to assist with survey design and the creation of a "shadowing project", in which librarians and staff from the two institutions observed each other at work to see what their similarities and differences might be. In addition, Childers surveyed the reference questions asked at San Jose State and San Jose Public and analyzed the results. It was revealed that the perception of public and academic librarianship as being fundamentally different from one another was primarily a myth. Although there were differences in how the public and academic librarians assisted their patrons, the questions themselves were not as different as some had thought. The results of this project and survey helped to convince some librarians and staff members of the feasibility of a combined reference desk and a merged reference collection.

\section{Usage patterns}

Surveys conducted by both the public library and the university library revealed that the university's heaviest periods of usage were during the weekday hours, while the public library saw most of its activity on evenings and weekends. Library planning teams anticipate that the complementary usage patterns will make crowding problems during peak periods less likely. Aird's article observes that: "Members of the public are by far the greater number of users but their usage pattern is such that generally they come in, choose their books, and leave. University students, on the other hand, will use the library 
for hours on end and have far more in-depth reference queries" (Aird et al 1998). In San Jose, although the public library's base of potential patrons dwarfs that of San Jose State University (over 900,000 city residents versus about 30,000 students), recent statistics show heavier usage of the university's library services (5400 daily average users versus 1700 for the public library's main branch).

The explosion in popularity of the Internet adds another dimension to Aird's observation, written in 1998 or possibly earlier. In the year 2002, one of the most popular services offered by any public library is public Internet access. Indeed, it has become a cliché to answer the question, "How many Internet terminals will I need in my new public library?" with the response "What is the population of your community?" Some of the university's librarians are concerned about the possibility of all the library's Internet terminals being occupied by public patrons, leaving no open machines for student use. Yet the most common solution to this dilemma, time limits on terminals, presents problems as well. A thirty-minute time limit on Internet usage is common in public libraries, yet in-depth database searches often require considerably more time. The ideal remedy for this problem is to have as many terminals as possible available to patrons.

\section{Other joint-use libraries}

Although many examples of joint-use libraries can be found, they have existed mostly in smaller communities. They have enjoyed considerable popularity in remote regions of Australia. The Dr. Martin Luther King, Jr. Library distinguishes itself from prior jointuse library endeavors through its size and its unique shared management system.

Author Alan Bundy sees four key success factors for joint use libraries: a formal agreement endorsed by all cooperating parties, a level of service to patrons equal to or greater than that which could be provided in separate facilities, system-wide support for staffing and professional development, and the establishment of a library management committee to develop policy and to determine goals and budget priorities. He believes most operating agreements he has seen to be deficient in four major areas: how space will be utilized, how to guarantee adequate staffing, how information technology will be acquired, supported, paid for, and used, and how the project will be evaluated (Bundy 1998).

Most of the joint-use library literature emphasizes the importance of an operating agreement. It is interesting to compare the King Library's Operating Agreement with that of another joint-use library. The Harmony Library in Fort Collins, Colorado is a joint-use facility shared by the Fort Collins Public Library and the Larimer campus of the Front Range Community College system. Although the project is not comparable in size to the new MLK library, their Intergovernmental Agreement nevertheless shares several characteristics with the San Jose Operating Agreement. The Harmony Library's IGA specifically states that they will use only one online catalog and circulation system, one collection, one classification system, one library card, and one set of policies and procedures. Exceptions to the one policy and procedure rule are allowed, but only to the extent that they are deemed necessary to fulfill the separate missions of the two institutions. The Harmony Library agreement also states that each party will select and 
purchase materials in accordance with its own collection development policy. In their library, the community college maintains the building and the grounds and provides security, custodial services, and phone lines (Dornseif 1999).

In the new King Library, there will be only one catalog, circulation system, and library card. However, most of the collection will remain separate and two classification schemes will be used. The San Jose State collection will continue to use the Library of Congress system, while the San Jose Public Library will maintain Dewey cataloging for its circulating collection. Exceptions to this general rule include the Reference section. A comparative study of the university's and public library's reference collections revealed very little duplication, which contributed to the decision to merge them. Services in the reference unit will be merged, and the public library is re-classifying its reference collection into LC so that it can be interfiled with the university's reference collection, although separate ownership tags will remain. Within the King Library, all library users will be able to access electronic databases, with the exception of a few that are passworded and limited to student and faculty use. Remote access to electronic databases that are purchased with university funds (rather than purchased jointly by both the university and the city) will be limited to SJSU student, staff, and faculty use.

Technical Services is a merged unit and a collaborative process will determine what hardware and software is purchased for the new library. Each organization is responsible for maintaining and replacing its own computer equipment from their respective operating budgets. Organizational staffing charts for each co-managed unit will break down the responsibility for shared components within the library. A good example is the organizational chart for the Information Technology department.

The King Library's collections will continue to be selected and purchased from separate organizational budgets; however, efforts are under way to coordinate collection development activities so that unnecessary duplication of materials is avoided. At the King Library, as at the Harmony Library, the university will maintain the building and grounds and provide security and custodial services. The operating agreement defines the percentage share based on square footage assigned to each organization and the mechanism by which the city will reimburse the university for its share of those services.

Other problems faced by joint-use library projects elsewhere remind the planners of the new MLK Library that they are not alone. As Dornseif writes, "For example, we have all been struggling to resolve our differences in philosophies on Internet access to provide a balance between popular e-mail and chat use and more traditional use of the Web for research (Dornseif 1999)." The planners of the new MLK Library face the same struggle. In the case of the Harmony Library, even the vice-president of the university admits that he was once convinced that the missions of an academic and public library were incompatible, but has since been proven wrong (Reno 1999)!

In size, the most comparable project to the King Library is the joint-use library at Nova Southeastern University in Florida. This library, open since the fall of 2002, also serves as the main public library for Broward County. As with the King Library, the university 
owns and operates the building. At Nova Southeastern, all library staff members are university employees, unlike the merged staff arrangement that will be used at the King Library. Although Broward County provides money for books, the university owns the entire collection. As in the King Library, separate classification schemes are used. In the Nova Southeastern library, like the planned arrangement of the King Library, the collections and services used most frequently by public patrons are located on the lower floors. One of the concerns raised by San Jose State University faculty and students regarding the King Library has been the possibility of excessive noise from children or young adults disturbing academic patrons who need a quiet study environment. However, in a telephone interview conducted on January 21, 2003, Don Riggs, dean of the Nova Southeastern library, reports no serious noise problems so far.

\section{Challenges and Opportunities}

The new library proposal met with opposition almost as soon as it was announced. A group of San Jose State University faculty led a vocal group calling themselves "S.O.U.L." ("Save Our University Library"). They were concerned that allowing public checkout of the university's research collection would lead to necessary research materials being unavailable to students when needed. Meanwhile San Jose community residents worried that the new library would divert funding from San Jose's smaller branch libraries. Each side feared that the other party would dominate resources and decision-making. The operating agreement, signed in December 1998, helped to assuage these fears.

Checkout of university materials by members of the public, possibly presenting access problems for San Jose State University students, was one of the first major areas of controversy regarding the new library. The Operating Agreement states that should problems arise regarding student access to books necessary for their classes, the city is obligated to help the university find a solution, including the possibility of restricting access to certain materials. Additionally, faculty members and students will be able to recall any books checked out by other library users, and faculty will retain their extended checkout privileges.

One of the most controversial aspects of the new King Library is the mixing of city and university employees under the same roof, in many cases performing similar functions, but with different supervisors and employing agencies. In Aird's article about joint-use libraries in Australia, some of the library managers warn against staff within the same institution working for different bodies, while others have used a structure in which a single library's staff is employed by two different entities with no serious problems (Aird 1998). In San Jose, concerns have been expressed about the proposed joint management structure of the new library. Some of the unions involved fear that employees of one institution may find themselves affected by the actions of a supervisor from the other institution. There are also concerns about the confidentiality of library employee job performance evaluations and health records. Several meetings were held where each of these issues was addressed. The unions will continue their practice of monitoring contracts as in the past. 
Another sticking point in the operational planning for the new library is who will staff the building during holidays and semester breaks, which occur at different times for each organization. While the public library's employees enjoy paid holidays scattered throughout the year, their university counterparts have semester breaks throughout the year, and paid leave in one block of time during the week after the Christmas holiday season. The co-managers are charged with setting staffing hours to assure an equitable service level for all users. In true collaborative spirit, one organization will support the other to ensure service delivery to all users. The university will staff the library during holidays observed by the city, while city employees will keep the library open during the week following Christmas.

Public art

As part of the City of San Jose's commitment to the arts, an ordinance requires that $2 \%$ of eligible capital improvement project budgets be set aside to support the installation of public art within the project. Internationally celebrated artist Mel Chin was selected through a highly competitive process to design the art for the new King Library. Mr. Chin is known for creating artworks that join cross-cultural aesthetics with complex ideas; he has worked with biologists, psychologists, geologists, physicians, and television producers. For the King Library, the artist researched the history of the Santa Clara Valley and its libraries to inform the artwork. Community forums were held to solicit public input. The diverse ranges of racial, age and socio-economic backgrounds among forum attendees ensured that multiple points of view would be represented in the design of the library artwork. Thirty-three initial installations have been located throughout the library, designed to pay homage to the book collection and encourage patrons to explore the library. Additional pieces will be proposed following the opening of the library. The art is expected to be a destination, and as with all art, a few pieces have caused controversy and stirred emotions. The artist and community members have met to share concerns and hear each other's views, and in all cases, a resolution or compromise was reached.

\section{Future trends}

Given today's pressures on library budgets, it is likely that in spite of whatever problems they may experience, joint-use library projects are here to stay. Limited budgets of statesupported educational institutions are frequently no longer sufficient to fund capital projects such as the King Library. Publicly-funded universities and schools, as well as state and local governments, must begin considering innovative new partnerships in order to meet the needs of their constituents.

There is also the more general benefit of exposing the community to the university, thus encouraging more communication and understanding between the city and the university. Frequently, universities seem disconnected from the communities in which they are located. The joint library project brings these two populations together in a new and innovative way. Additionally, the California State University system exists in part to serve the needs of California's less-affluent students. It is hoped that exposing young readers to the higher education environment will help them realize that the university is truly open to anyone. 
The economies of scale on a large project of this nature provide benefits far beyond the initial outlay of capital. For example, for the public library to erect a new structure with enough space for 25 years of growth would have required a building of 200,000 square feet. The equivalent requirement in the shared facility resulted in 170,000 square feet, allowing for that 25 years of growth. This is due to common areas such as restrooms, study areas, meeting spaces, mailroom areas, shipping and receiving areas, and staff break rooms being shared. Both organizations benefit in long-term operational costs as well. Each will pay less for maintenance, security services, and long-term replacement costs than either would with separate buildings. Shared resources such as one library catalog system, one telephone system, self-check out machines, and shared service points truly make the new King Library a facility whose whole is greater than the sum of its parts. Finally, the cost savings and increased efficiency of the joint-use library creates a win-win situation for taxpayers, as both institutions find that their collections are enhanced by the presence and availability of access to the other's materials.

The library is scheduled to open to the public on August $1^{\text {st }}, 2003$, with a grand opening celebration scheduled for August 23, 2003. There is a lot of excitement and a lot of fear as well, as we move into the unknown. Although many of the details are still sketchy, as the first large-scale joint-use venture of its kind in the nation, there are no existing models to work from: ergo, policies and procedures in the new library will be adjusted and adapted as our learning curve dictates. The bottom line is: This project will work if we want it to work. Browne (1981), writing about joint-use libraries in Australia, says she is "naïve enough to believe that any management structure, no matter how poor, can be made to work provided there is sufficient goodwill on both sides; and conversely that any management structure, no matter how technically perfect, will fail if one of the parties, consciously or unconsciously wants it to do so." The advantage in San José is that each decision maker involved is committed to making this unique, highly leveraged joint library project work. 


\section{References}

About Broward County Library (2002) [Online]. Available:

http://www.broward.org/library/about.htm [2002, July 8].

Agreement for ownership and operation of joint library building and grant of easement (1998). Available at: http://www.newkinglibrary.org/pdfs/operating_agreement.pdf (accessed 24 January 2003).

Aird, G., Bergoc, A., Dunford, H., Hamblin, D., Perkins, S., \& Shepherd, C. (1998), "Joint use libraries in Australia: practitioner perspectives", Australasian Public Libraries and Information Services [Electronic], vol. 11 no. 4, pp. 174 (1). Available: Expanded Academic ASAP [2002, August 8].

Amey, L. J. (1987), “Joint-use library evaluation: a plan for assessing the performance and progress of joint-use libraries", in Amey, L. J. (Ed), Combining libraries: the Canadian and Australian experience, Scarecrow Press, Inc., Metuchen, New Jersey, pp. 224-241.

Anderson Brule Architects, Inc. (1999), Strategic Operational Plan for the San Jose Joint Library (internal working document).

Atagi, C. (2001), "Library skeleton nearly complete", Spartan Daily, 11 December, pp. $1(3)$.

Bartindale, B. (1998), "City-SJSU library gets council OK joint venture: Vote approves pursuing plans for unique facility. Council will pursue joint library plan", San Jose Mercury News [Electronic], 22 May, pp. 1B. Available: Newsbank [2003, January 24].

Bartindale, B. (1998), "'Issues of money, control still must be hashed out before union can work checking out idea of city-SJSU library", San Jose Mercury News [Electronic], 22 February, pp. 1A. Available: Newsbank [2003, January 24].

Bartindale, B. (1998), "Joint library drive to begin high profile team sets $\$ 16.5$ million goal for city-university project", San Jose Mercury News [Electronic], 29 December, pp. 1B. Available: Newsbank [2003, January 24].

Bartindale, B. (1998), "Joint S.J. library set for final votes make-or-break issue: Who will use the books?", San Jose Mercury News [Electronic], 6 December, pp. 1A. Available: Newsbank [2003, January 24].

Bartindale, B. (1999), "Library might not get King name some fear city, SJSU will sell title to the highest bidder", San Jose Mercury News [Electronic], 16 April, pp. 1A. Available: Newsbank [2003, January 24].

Bartindale, B. (1998), "Reading up on proposed library answers to some basic questions on the joint venture between San Jose, San Jose State", San Jose Mercury News [Electronic], 6 September, pp. 1B. Available: Newsbank [2003, January 24]. 
Bartindale, B. (1998), "Smaller, costlier joint library awaits first key council vote San Jose, SJSU propose 6-story campus facility", San Jose Mercury News [Electronic], 14 May, pp. 1A. Available: Newsbank [2003, January 24].

Bhatia, S. (2002), Responses to MEF Regarding Joint Library Issues (internal working document).

Brewer, S. (2002), "County will join college in building new library", Houston Chronicle [Electronic], 17 January, pp. 23. Available: Dow Jones Interactive [2002, November 23].

Browne, A. (1981) "Joint use libraries in colleges: New directions in Tafe", in Joint Use Libraries in the Australian Community, Proceedings of a National Workshop Melbourne 13-15 August 1980, National Library of Australia, Canberra.

Bundy, A. (1998), "Widening client horizons: joint use libraries in the 1990s", Australasian Public Libraries and Information Services [Electronic], vol. 11 no. 1, pp. 4-16. Available: Wilson Web [2002, July 11].

Burbach, C. (1999), "Library trustees OK plan with metro; library", Omaha WorldHerald [Electronic], 19 August, pp. 15. Available: Dow Jones Interactive [2002, November 23].

Byrne, M. (2000), "Seminole, SJPC hire architect for library", North Pinellas Times [Electronic], 26 November, pp. 14. Available: Dow Jones Interactive [2002, August 1].

"Call for a leap of faith joint library idea requires caution" (1998), San Jose Mercury News [Electronic], 21 May, pp. 8B. Available: Newsbank [2003, January 24].

Call, L.S. (1993), “Joint-use libraries: just how good are they?", College \& Research Libraries News, November 1993, pp. 551-552.

"Can a city-university library work? San Jose State University and city systems will not easily meld-and the benefits are unclear" (1997), San Jose Mercury News [Electronic], 15 February, pp. 7B. Available: Newsbank [2003, January 24].

Canon, K. (2002), “Group against city-county library plan”, Houston Chronicle [Electronic], 20 June, pp. 1. Available: Dow Jones Interactive [2002, July 10].

Chin, M. (undated), Design Proposal for the San Jose Joint Library Public Art Collection (internal working document).

City of San Jose/San Jose State University (2000), Joint Library Leadership Structure (internal working document).

Conaway, P. (2000), “One reference service for everyone?”, Library Journal [Electronic], vol. 125 no. 12, pp. 42-44. Available: Wilson Web [2002, July 31]. 
Connelly, L. and Leal, F. (2002), "Mariners library wins approval/City council, school district endorse the joint-use project", Orange County Register [Electronic], 13 June, pp. 1. Available: Dow Jones Interactive [2002, July 10].

Cronk, M. (1998), "City approves joint library with SJSU 10-1 vote allows construction to begin in spring 2000" San Jose Mercury News [Electronic], 18 December, pp. 1A. Available: Newsbank [2003, January 24].

Culture Vision Statement (undated), (internal working document).

Dornseif, K., \& Willis, E. (1999), "Making the joint-use library work: Harmony Library, Fort Collins, Colorado", Colorado Libraries [Electronic], vol. 25 no. 2, pp. 1517. Available: Wilson Web [2002, July 31].

Duan, M. (2002), "Big project? No problem: Joint library plan encountering few unresolved issues", Silicon Valley/San Jose Business Journal, 12 April, pp. 23 (46).

Dunford, H. (1998), "Cooperation, compromise, commitment: a joint use library in an isolated area of Tasmania", Australasian Public Libraries and Information Services [Electronic], vol. 11 no. 4, pp. 179-181. Available: Wilson Web [2002, July 31].

Egner, D. (1998), "Public to get look at S.J. joint library project input: Two sessions will be held to discuss \$171 million plan", San Jose Mercury News [Electronic], 27 August, pp. 6B. Available: Newsbank [2003, January 24].

Egner, D. (1998), "San Jose-SJSU library plan to be discussed" (1997), San Jose Mercury News [Electronic], 2 October, pp. 6B. Available: Newsbank [2003, January 24].

"Florida's largest library to have topping-off ceremony at Nova Southeastern University on March 30 at 10:30 A.M." (2001), Business Wire, 27 March. Available: Dow Jones Interactive [2002, August 1].

Freeman, A. (2001), “An innovative library partnership", Planning for Higher Education, vol. 30 no. 1, pp. 20-26.

Gaura, M.A. (2000), “A NEW LEAF/Plans are going smoothly for nation's first joint city-university library”, San Francisco Chronicle [Electronic], 25 May, pp. A17.

Available: Dow Jones Interactive [2002, November 23].

Gluck, G.H. (2001), "Checking out new agreement near on joint library for Mendhams", Star-Ledger (Newark, NJ) [Electronic], 24 July, pp. 15. Available: Dow Jones Interactive [2002, November 23].

Gonzalez, C. (2002), “Achola revives S. Omaha library debate: The library board member plans to ask for reconsideration of a proposal to share a facility with Metro Community College", Omaha World-Herald [Electronic], 1 March, pp. 1A. Available: Lexis-Nexis [2002, August 1]. 
Guernsey, L. (1999), "In San José, city and university move ahead with plans for a joint library", The Chronicle of Higher Education [Electronic], vol. 45 no. 20, pp. A21.

Available: Lexis-Nexis [2002, July 10].

Guernsey, L. (1999), "Report questions San José plan for joint city-university library", The Chronicle of Higher Education [Electronic], vol. 45 no. 25, pp. A25. Available: Lexis-Nexis [2002, August 1].

Guernsey, L. (1998), "Should a college and a city share a single library?", The Chronicle of Higher Education [Electronic], vol. 45 no. 10, pp. A25-A26. Available: Lexis-Nexis [2002, July 10].

Hazle, B. (2001), "City-school library considered/Oceanside weighing a partnership idea", San Diego Union-Tribune [Electronic], 19 July, pp. NC-2. Available: Dow Jones Interactive [2002, November 23].

Henneman, T. (1998), "Foes call plan for joint library 'harebrained'/City of San Jose, university would build combined facility", San Francisco Chronicle [Electronic], 14 October, pp. A15. Available: Dow Jones Interactive [2002, October 14].

Hoang, M. (2002), "Pewaukee village officials air concerns on library", Milwaukee Journal Sentinel [Electronic], 28 June, pp. 4B. Available: Dow Jones Interactive [2002, July 10].

Irving, C. (2001), “A town and gown library: City joins San Jose State University in collaborative arrangement", National Crosstalk, Fall 2001, pp. 6-7.

Joint Library Memorandum of Understanding (undated). Available at:

http://www.newkinglibrary.org/progress/two-2.html (accessed 24 January 2003).

Joint Library Organizational Design Teams, Collaborative Leadership, and Quality Solutions Process Tools Session (2000), (internal working document).

Jordan, H. and Bartindale, B. (1999), "State official says city-SJSU plan too costly library proposal attacked", San Jose Mercury News [Electronic], 17 February, pp. 1B. Available: Newsbank [2003, January 24].

Karp, R.S. (1996), “The literature of joint-use libraries”, in Williams, Delmus E., and Garten, Edward D. (Eds), Advances in library administration and organization, volume 14, JAI Press, Inc., Greenwich, Connecticut, pp. 227-271.

Kelly, E.M. (1996), "City, college may share high-tech library”, Orange County Register [Electronic], 21 November, pp. 01. Available: Dow Jones Interactive [2002, November 23].

Kinsey, S. and Honing-Bear, S. (1994), "Joint-use libraries: more bang for your bucks", Wilson Library Bulletin [Electronic], vol. 69 (November). Available: Wilson Web [2002, November 23]. 
Kumar, A. (1998), "City rejects SJPC's deal for joint library”, St. Petersburg Times [Electronic], 7 November, pp. 1. Available: Dow Jones Interactive [2002, November 23].

Leal, F. (2001), "City, school district to partner on library/The Mariners Joint Use Library will serve as Mariners Elementary School's library”, Orange County Register [Electronic], 27 December, pp. 1. Available: Dow Jones Interactive [2002, November 23].

Leal, F., Connelly, L. and Martinez, B. (2002), "Joint-use library approved in Newport/Cities-city council, school district OK facility to be used by Mariners Elementary as well as the public", Orange County Register [Electronic], 12 June, pp. 1. Available: Dow Jones Interactive [2002, August 1].

"Library co-op splits in Pennsylvania: colleges part company, dissolving joint library after 20 years" (1993), Library Journal, vol. 118 (15 October), pp. 14.

"Library named for MLK state hurdle cleared for new S.J. facility" (2000), San Jose Mercury News [Electronic], 11 May, pp. 2B. Available: Newsbank [2003, January 24].

Library Technical Team Findings (undated). Available at: http://www.newkinglibrary.org/progress/two-2.html (accessed 24 January 2003).

Light, J. (2002), "Miracle on $4^{\text {th }}$ Street, the new Dr. Martin Luther King, Jr. Library". Presentation delivered at American Library Association conference, 15 June.

Malchow, A. (2001), "Diverse board has task of getting final funds for joint library", Silicon Valley/San Jose Business Journal [Electronic], 25 May. Available at: http://sanjose.bizjournals.com/sanjose/ (accessed 24 January 2003).

Marshall, J. (1998), “City likes proposal to share library”, St. Petersburg Times [Electronic], 5 April, pp. 1. Available: Dow Jones Interactive [2002, November 23].

Marshall, J. (1998), “Council backs joint library plan”, St. Petersburg Times [Electronic], 9 December, pp. 1. Available: Dow Jones Interactive [2002, November 23].

McPherson, M., Curry, D., \& Humphreys, J. (1998), "Hervey Bay joint use library: lessons for tomorrow", Australasian Public Libraries and Information Services [Electronic], vol. 11 no. 2, pp.75-89. Available: Wilson Web [2002, July 31].

Nevins, K. (1997), "Partnerships and competition". Invited paper: Association of College \& Research Libraries National Conference, Nashville, Tennessee, April 11-14, 1997. Available at: http://www.ala.org/acrl/invited/nevins.html (accessed 12 July 2002).

The new Dr. Martin Luther King, Jr. library: Learning for life (undated promotional brochure). 
"Nova Southeastern unveils \$43 million, five-story library" (2001), Associated Press State \& Local Wire, 8 December. Available: Lexis-Nexis [2002, November 22].

"NSU Library, Research, and Information Technology Center" (2002) [Online]. Available: http://www.broward.org/library/nova.htm [2002, July 11].

O'Connor, M. (2001), “Omaha, Metro College finalize land purchases”, Omaha WorldHerald [Electronic], 1 August, pp. 14. Available: Lexis-Nexis [2002, July 10].

"Opinion: New library key to SJ revitalization efforts" (2002), Silicon Valley Biz Ink [Electronic], 21-27 February. Available at: http://www.svbizink.com/ (accessed 24 January 2003).

Ping, K. (2002), "Toward continual reform: progress in academic libraries in China", College \& Research Libraries [Electronic], vol. 63 no. 2, pp. 164-170. Available: Wilson Web [2002 July 11].

Plauché, P. (2000), "Pearlington Public Library: a joint use school/library facility", Mississippi Libraries, vol. 64 no. 3, pp. 81-82.

Public Forums, 1998 (undated). Available at:

http://www.newkinglibrary.org/progress/two-2.html (accessed 24 January 2003).

Puzzanghera, J. (1997), "Speakers resist joint-library idea hearing: Uniting city, SJS facility a bad idea, most agree", San Jose Mercury News [Electronic], 5 October, pp. 1B. Available: Newsbank [2003, January 24].

Ralston, Y. L., \& Oldenburg, A. (1992), "Joint-use library services at distant campuses: building cooperation between a community college and a university", in McCabe, G. B. (Ed), Academic libraries in urban and metropolitan areas: a management handbook, Greenwood Press, Westport, Connecticut, pp. 143-58.

Reno, E. E. (1999), “Joint-use libraries: a college president's perspective", Colorado Libraries [Electronic], vol. 25 no. 2, pp. 10-11. Available: Wilson Web [2002 July 11].

Responses to CSEA Questions (2002), (internal working document).

Rondeaux, C. (2002), "Library users wary of relocation plans", St. Petersburg Times [Electronic], 7 July, pp. 7. Available: Dow Jones Interactive [2002, July 10].

Russell, S.N. (2002), "Tale of a library site: Like no other, for a community like no other, with partners like no other", SEARCH: SouthNet News, vol. 24 no. 4 (2002 June), pp. 1-2.

Schwanz, K. (2000), “Thinking about a joint-use library?", College and Research Libraries News [Electronic], vol. 61 no. 6, pp. 478-480. Available at: http://www.ala.org/acrl/schwanz.html (accessed 12 July 2002). 
Schutz, J. and Kline, K. (2002), "San Jose partnership creates a new city-university library", Western City [Electronic], September. Available at:

http://www.westerncity.com/Sept02SanJosePartnership.htm (accessed 24 January 2003).

Shepherd, M. C. (1998), "The truth is in the details: lessons in inter-university library collaboration", International Association of Technological University Libraries

Conference Proceedings, vol. 8. Available at:

http://www.iatul.org/conference/pretpap/shepherd.html (accessed 1 August 2002).

Shier, C. (1999), "Resource sharing: case study of a new joint use library in South Australia", Australasian Public Libraries and Information Services [Electronic], vol. 12 no. 3, pp. 123-127. Available: Wilson Web [2002 July 11].

Sloan, S. (2002), "New library violates employee-manager confidentiality", CSEA/CSU Labor Update [2002 July 29]. Available at: http://www.labor.sjsu.edu/union/news/20020802.htm (accessed 16 December 2002).

Stinebaker, J. (1999), "Plan for joint library shelved/City, county to build 2 facilities 2 miles apart", Houston Chronicle [Electronic], 6 January, pp. 1. Available: Dow Jones Interactive [2002, November 23].

Stinebaker, J. and Schwartz, M. (1999), "Joint-library negotiations topple again/City, county to build two nearby facilities", Houston Chronicle [Electronic], 25 February, pp. 21. Available: Dow Jones Interactive [2002, November 23].

Subcommittee recommendations on library technical team report (undated). Available at: http://www.newkinglibrary.org/progress/two2.html (accessed 24 January 2003).

Summary of the public hearing conducted by the Academic Senate Special Committee on the joint library project (1998). Available at:

http://www.newkinglibrary.org/progress/two2.html (accessed 24 January 2003).

Taylor, D. (2003), "Big names lead library fund-raising effort", Silicon Valley Biz Ink [Electronic], 21-27 February. Available at: http://www.svbizink.com/ (accessed 24 January 2003).

Tubbs, S. (1998), "SPJC, Clearwater consider joint library", St. Petersburg Times [Electronic], 19 March, pp. 12. Available: Dow Jones Interactive [2002, November 23].

Van Digglen, A.R.G. (2002), “Booked for success”, San Jose, February.

"Vote of confidence opening books" (1998), San Jose Mercury News [Electronic], 9 December, pp. 6B. Available: Newsbank [2003, January 24].

"Webster University begins construction of new library" (2001) [Online]. Available: http://www.webster.edu/news/currentreleases/librarygb.html [2002, July 11]. 
Welter, C. (2002), "San Jose State dean a front-runner in ambitious library collaboration", Silicon Valley/San Jose Business Journal, 12 April, pp. 46.

Wilson, L.A. (2002), "Collaborate or die: designing library space”, ARL [Electronic], no. 222, pp. 1-3. Available at: http://www.arl.org/newsltr/222/collabwash.html (accessed 22 November 2002).

Witt, B. (1997), "Joint city-SJSU library proposed mayor forecasts era of stability, well-being", San Jose Mercury News [Electronic], 4 February, pp. 1A. Available: Newsbank [2003, January 24].

Witt, B. (1997), "Library price elusive $\$ 40$ million estimate may be way off", San Jose Mercury News [Electronic], 8 February, pp. 1B. Available: Newsbank [2003, January 24].

Wright, S. (1994), “Joint library set for fall ground-breaking”, Columbus Dispatch [Electronic], 1 May, pp. 02B. Available: Dow Jones Interactive [2002, November 23].

Yang, E. L., Hashert, C., \& Evans, L. (2001), "Auraria Library and Media Center, a best kept secret? NOT!”, Colorado Libraries, vol. 27 no. 4, pp. 32-34. 


\section{Further reading}

Agreement for ownership and operation of joint library building and grant of easement (1998). Available at: http://www.newkinglibrary.org/pdfs/operating_agreement.pdf (accessed 24 January 2003).

Amey, L. J. (1987), “Joint-use library evaluation: a plan for assessing the performance and progress of joint-use libraries", in Amey, L. J. (Ed), Combining libraries: the Canadian and Australian experience, Scarecrow Press, Inc., Metuchen, New Jersey, pp. 224-241.

Anderson Brule Architects, Inc. (1999), Strategic Operational Plan for the San Jose Joint Library (internal working document).

Atagi, C. (2001), "Library skeleton nearly complete”, Spartan Daily, 11 December, pp. $1(3)$.

Bartindale, B. (1998), "City-SJSU library gets council OK joint venture: Vote approves pursuing plans for unique facility. Council will pursue joint library plan", San Jose Mercury News [Electronic], 22 May, pp. 1B. Available: Newsbank [2003, January 24].

Bartindale, B. (1998), "'Issues of money, control still must be hashed out before union can work checking out idea of city-SJSU library", San Jose Mercury News [Electronic], 22 February, pp. 1A. Available: Newsbank [2003, January 24].

Bartindale, B. (1998), "Joint library drive to begin high profile team sets $\$ 16.5$ million goal for city-university project", San Jose Mercury News [Electronic], 29 December, pp. 1B. Available: Newsbank [2003, January 24].

Bartindale, B. (1998), "Joint S.J. library set for final votes make-or-break issue: Who will use the books?", San Jose Mercury News [Electronic], 6 December, pp. 1A. Available: Newsbank [2003, January 24].

Bartindale, B. (1999), "Library might not get King name some fear city, SJSU will sell title to the highest bidder", San Jose Mercury News [Electronic], 16 April, pp. 1A. Available: Newsbank [2003, January 24].

Bartindale, B. (1998), "Reading up on proposed library answers to some basic questions on the joint venture between San Jose, San Jose State", San Jose Mercury News [Electronic], 6 September, pp. 1B. Available: Newsbank [2003, January 24].

Bartindale, B. (1998), "Smaller, costlier joint library awaits first key council vote San Jose, SJSU propose 6-story campus facility", San Jose Mercury News [Electronic], 14 May, pp. 1A. Available: Newsbank [2003, January 24].

Bhatia, S. (2002), Responses to MEF Regarding Joint Library Issues (internal working document). 
"Call for a leap of faith joint library idea requires caution" (1998), San Jose Mercury News [Electronic], 21 May, pp. 8B. Available: Newsbank [2003, January 24].

Call, L.S. (1993), “Joint-use libraries: just how good are they?”, College \& Research Libraries News, November 1993, pp. 551-552.

"Can a city-university library work? San Jose State University and city systems will not easily meld-and the benefits are unclear" (1997), San Jose Mercury News [Electronic], 15 February, pp. 7B. Available: Newsbank [2003, January 24].

Chin, M. (undated), Design Proposal for the San Jose Joint Library Public Art Collection (internal working document).

City of San Jose/San Jose State University (2000), Joint Library Leadership Structure (internal working document).

Conaway, P. (2000), “One reference service for everyone?”, Library Journal [Electronic], vol. 125 no. 12, pp. 42-44. Available: Wilson Web [2002, July 31].

Cronk, M. (1998), "City approves joint library with SJSU 10-1 vote allows construction to begin in spring 2000" San Jose Mercury News [Electronic], 18 December, pp. 1A. Available: Newsbank [2003, January 24].

Culture Vision Statement (undated), (internal working document).

Duan, M. (2002), "Big project? No problem: Joint library plan encountering few unresolved issues", Silicon Valley/San Jose Business Journal, 12 April, pp. 23 (46).

Dunford, H. (1998), "Cooperation, compromise, commitment: a joint use library in an isolated area of Tasmania", Australasian Public Libraries and Information Services [Electronic], vol. 11 no. 4, pp. 179-181. Available: Wilson Web [2002, July 31].

Egner, D. (1998), "Public to get look at S.J. joint library project input: Two sessions will be held to discuss \$171 million plan", San Jose Mercury News [Electronic], 27 August, pp. 6B. Available: Newsbank [2003, January 24].

Egner, D. (1998), "San Jose-SJSU library plan to be discussed" (1997), San Jose Mercury News [Electronic], 2 October, pp. 6B. Available: Newsbank [2003, January 24].

"Florida's largest library to have topping-off ceremony at Nova Southeastern University on March 30 at 10:30 A.M.” (2001), Business Wire, 27 March. Available: Dow Jones Interactive [2002, August 1].

Freeman, A. (2001), “An innovative library partnership", Planning for Higher Education, vol. 30 no. 1, pp. 20-26. 
Gaura, M.A. (2000), “A NEW LEAF/Plans are going smoothly for nation's first joint city-university library", San Francisco Chronicle [Electronic], 25 May, pp. A17.

Available: Dow Jones Interactive [2002, November 23].

Guernsey, L. (1999), "In San José, city and university move ahead with plans for a joint library", The Chronicle of Higher Education [Electronic], vol. 45 no. 20, pp. A21. Available: Lexis-Nexis [2002, July 10].

Guernsey, L. (1999), "Report questions San José plan for joint city-university library", The Chronicle of Higher Education [Electronic], vol. 45 no. 25, pp. A25. Available: Lexis-Nexis [2002, August 1].

Guernsey, L. (1998), "Should a college and a city share a single library?", The Chronicle of Higher Education [Electronic], vol. 45 no. 10, pp. A25-A26. Available: Lexis-Nexis [2002, July 10].

Henneman, T. (1998), "Foes call plan for joint library 'harebrained'/City of San Jose, university would build combined facility", San Francisco Chronicle [Electronic], 14 October, pp. A15. Available: Dow Jones Interactive [2002, October 14].

Irving, C. (2001), "A town and gown library: City joins San Jose State University in collaborative arrangement”, National Crosstalk, Fall 2001, pp. 6-7.

Joint Library Memorandum of Understanding (undated). Available at: http://www.newkinglibrary.org/progress/two-2.html (accessed 24 January 2003).

Joint Library Organizational Design Teams, Collaborative Leadership, and Quality Solutions Process Tools Session (2000), (internal working document).

Jordan, H. and Bartindale, B. (1999), "State official says city-SJSU plan too costly library proposal attacked", San Jose Mercury News [Electronic], 17 February, pp. 1B. Available: Newsbank [2003, January 24].

Karp, R.S. (1996), "The literature of joint-use libraries", in Williams, Delmus E., and Garten, Edward D. (Eds), Advances in library administration and organization, volume 14, JAI Press, Inc., Greenwich, Connecticut, pp. 227-271.

Kinsey, S. and Honing-Bear, S. (1994), "Joint-use libraries: more bang for your bucks", Wilson Library Bulletin [Electronic], vol. 69 (November). Available: Wilson Web [2002, November 23].

"Library co-op splits in Pennsylvania: colleges part company, dissolving joint library after 20 years" (1993), Library Journal, vol. 118 (15 October), pp. 14.

"Library named for MLK state hurdle cleared for new S.J. facility" (2000), San Jose Mercury News [Electronic], 11 May, pp. 2B. Available: Newsbank [2003, January 24]. 
Library Technical Team Findings (undated). Available at:

http://www.newkinglibrary.org/progress/two-2.html (accessed 24 January 2003).

Light, J. (2002), "Miracle on $4^{\text {th }}$ Street, the new Dr. Martin Luther King, Jr. Library". Presentation delivered at American Library Association conference, 15 June.

Malchow, A. (2001), "Diverse board has task of getting final funds for joint library", Silicon Valley/San Jose Business Journal [Electronic], 25 May. Available at: http://sanjose.bizjournals.com/sanjose/ (accessed 24 January 2003).

McPherson, M., Curry, D., \& Humphreys, J. (1998), "Hervey Bay joint use library: lessons for tomorrow", Australasian Public Libraries and Information Services [Electronic], vol. 11 no. 2, pp.75-89. Available: Wilson Web [2002, July 31].

Nevins, K. (1997), "Partnerships and competition". Invited paper: Association of College \& Research Libraries National Conference, Nashville, Tennessee, April 11-14, 1997. Available at: http://www.ala.org/acrl/invited/nevins.html (accessed 12 July 2002).

The new Dr. Martin Luther King, Jr. library: Learning for life (undated promotional brochure).

"Nova Southeastern unveils \$43 million, five-story library" (2001), Associated Press State \& Local Wire, 8 December. Available: Lexis-Nexis [2002, November 22].

"NSU Library, Research, and Information Technology Center" (2002) [Online]. Available: http://www.broward.org/library/nova.htm [2002, July 11].

"Opinion: New library key to SJ revitalization efforts" (2002), Silicon Valley Biz Ink [Electronic], 21-27 February. Available at: http://www.svbizink.com/ (accessed 24 January 2003).

Plauché, P. (2000), "Pearlington Public Library: a joint use school/library facility", Mississippi Libraries, vol. 64 no. 3, pp. 81-82.

Public Forums, 1998 (undated). Available at: http://www.newkinglibrary.org/progress/two-2.html (accessed 24 January 2003).

Puzzanghera, J. (1997), "Speakers resist joint-library idea hearing: Uniting city, SJS facility a bad idea, most agree", San Jose Mercury News [Electronic], 5 October, pp. 1B. Available: Newsbank [2003, January 24].

Ralston, Y. L., \& Oldenburg, A. (1992), "Joint-use library services at distant campuses: building cooperation between a community college and a university", in McCabe, G. B. (Ed), Academic libraries in urban and metropolitan areas: a management handbook, Greenwood Press, Westport, Connecticut, pp. 143-58.

Responses to CSEA Questions (2002), (internal working document). 
Russell, S.N. (2002), "Tale of a library site: Like no other, for a community like no other, with partners like no other", SEARCH: SouthNet News, vol. 24 no. 4 (2002 June), pp. 1-2.

Schwanz, K. (2000), “Thinking about a joint-use library?”, College and Research Libraries News [Electronic], vol. 61 no. 6, pp. 478-480. Available at: http://www.ala.org/acrl/schwanz.html (accessed 12 July 2002).

Schutz, J. and Kline, K. (2002), "San Jose partnership creates a new city-university library", Western City [Electronic], September. Available at: http://www.westerncity.com/Sept02SanJosePartnership.htm (accessed 24 January 2003).

Shier, C. (1999), "Resource sharing: case study of a new joint use library in South Australia", Australasian Public Libraries and Information Services [Electronic], vol. 12 no. 3, pp. 123-127. Available: Wilson Web [2002 July 11].

Sloan, S. (2002), "New library violates employee-manager confidentiality", CSEA/CSU Labor Update [2002 July 29]. Available at: http://www.labor.sjsu.edu/union/news/20020802.htm (accessed 16 December 2002).

Subcommittee recommendations on library technical team report (undated). Available at: http://www.newkinglibrary.org/progress/two2.html (accessed 24 January 2003).

Summary of the public hearing conducted by the Academic Senate Special Committee on the joint library project (1998). Available at:

http://www.newkinglibrary.org/progress/two2.html (accessed 24 January 2003).

Taylor, D. (2003), "Big names lead library fund-raising effort", Silicon Valley Biz Ink [Electronic], 21-27 February. Available at: http://www.svbizink.com/ (accessed 24 January 2003).

Van Digglen, A.R.G. (2002), "Booked for success”, San Jose, February.

"Vote of confidence opening books" (1998), San Jose Mercury News [Electronic], 9 December, pp. 6B. Available: Newsbank [2003, January 24].

Welter, C. (2002), "San Jose State dean a front-runner in ambitious library collaboration”, Silicon Valley/San Jose Business Journal, 12 April, pp. 46.

Wilson, L.A. (2002), "Collaborate or die: designing library space", $A R L$ [Electronic], no. 222, pp. 1-3. Available at: http://www.arl.org/newsltr/222/collabwash.html (accessed 22 November 2002).

Witt, B. (1997), "Joint city-SJSU library proposed mayor forecasts era of stability, wellbeing", San Jose Mercury News [Electronic], 4 February, pp. 1A. Available: Newsbank [2003, January 24]. 
Witt, B. (1997), "Library price elusive \$40 million estimate may be way off", San Jose Mercury News [Electronic], 8 February, pp. 1B. Available: Newsbank [2003, January 24].

Yang, E. L., Hashert, C., \& Evans, L. (2001), "Auraria Library and Media Center, a best kept secret? NOT!", Colorado Libraries, vol. 27 no. 4, pp. 32-34. 